DOI: $10.4067 /$ S0718-16202014000300013

RESEARCH NOTE

\title{
Growth, yield and iron deficiency tolerance level of six peach rootstocks grown on calcareous soil
}

\author{
Carlos Sotomayor ${ }^{1}$, Rafael Ruiz ${ }^{2}$, and Jorge Castro ${ }^{1}$ \\ 'Pontificia Universidad Católica de Chile. Facultad de Agronomía e Ingeniería Forestal. Casilla 306-22, \\ Santiago, Chile. \\ ${ }^{2}$ Instituto de Investigaciones Agropecuarias. CRI La Platina. Santa Rosa 11610, La Pintana, Santiago, Chile.
}

\begin{abstract}
C. Sotomayor, R. Ruiz, and J. Castro. 2014. Growth, yield and iron deficiency tolerance level of six peach rootstocks grown on calcareous soil. Cien. Inv. Agr. 41(3):403-409. Iron deficiency is a major problem that affects many fruit crops grown on calcareous soils. A fouryear study was conducted to evaluate the effect of calcareous soils on the vegetative growth and productivity of six peach rootstocks (Nemaguard, Atlas, MRS 2/5, Cadaman, GF 677 and GxN15) grafted with 'Ruby Diamond' nectarines. Trees were planted in $100 \mathrm{~L}$ containers filled with a sandy loam textured, calcareous soil ( $6.3 \%$ active calcium carbonate) with a $\mathrm{pH}$ of 8.0 and an intermediate level of available iron $\left(5 \mathrm{mg} \mathrm{kg}^{-1} \mathrm{of} \mathrm{Fe}^{+2}\right)$. The trunk diameter during the $4^{\text {th }}$ growing season was larger in GF 677, GN 15, Cadaman and Atlas, whereas Nemaguard and MRS 2/5 showed smaller average values. Cadaman and Atlas presented the highest pruning weight (a measure of vegetative growth), GxN 15 and GF 677 were intermediate, and Nemaguard and MRS 2/5 exhibited the lowest weight. In the fourth year, yield per tree was higher in Atlas and Cadaman, while Nemaguard had the lowest yield. MRS 2/5 and GxN 15 had the highest individual fruit weights, particularly when compared with Cadaman. Regarding leaf chlorosis, the most severe symptoms were exhibited by Nemaguard $\left(12.3 \mathrm{mg} \mathrm{kg}^{-1}\right.$ of active iron), with mild symptoms in Atlas and slight to no symptoms in Cadaman, MRS 2/5 and GxN 15. Leaf chlorosis was not observed in GF 677 (26.4 mg kg-1 of active iron). All rootstocks, especially GF 677 , showed better performance than Nemaguard with respect to chlorophyll measurements of the leaves obtained through the SPAD technique.
\end{abstract}

Key words: Calcareous soil, $\mathrm{Fe}^{+2}$, iron chlorosis, peach rootstock, SPAD.

\section{Introduction}

Iron $(\mathrm{Fe})$ deficiency is a major problem for fruit crops grown on calcareous or lime (high $\mathrm{pH}$ ) soils (Tsipouridis et al., 2005). Leaf chlorosis is the

Received January 7, 2014. Accepted November 6, 2014. Corresponding author: csotomas@gmail.com most characteristic symptom, in which the leaves are pale or yellow and the veins remain green. If the deficiency is mild to moderate, it only affects young leaves; however, if it is severe, it will affect the entire plant (Tagliavini and Rombolà, 2001). Another characteristic symptom is a reduction in growth and productivity; in grapevines, growth may be affected before leaf chlorosis is observed (Romheld, 2000). It is believed that calcareous 
soils lack available iron, apart from any problems with absorption and translocation within the plants (Mengel, 1995). Koseoglua (1995) noted that $\mathrm{HCl}$-extractable iron content is negatively correlated with the calcium carbonate and calcium bicarbonate contents in soils.

Peaches are an important fruit crop in many countries, and mineral nutrition is one of the factors that most significantly affects tree productivity and fruit quality. Many orchards are located in areas with calcareous soils, increasing the possibility that they may develop iron chlorosis (Ruiz et al., 1984; Toselli et al., 2000). Despite the high Fe concentrations in the roots and leaves of vines grown in calcareous soils, the plants can suffer from Fe deficiency (Gruber and Kosegarten, 2002). According to Koseoglua (1995), the availability of Fe and its absorption by peach roots is significantly affected by high $\mathrm{pH}$ and the presence of carbonates and bicarbonates in the soil, and the resulting iron deficiency often manifests as leaf chlorosis. However, there is no relationship between the total Fe concentration in leaf tissue and the development of iron chlorosis (Ruiz et al., 1984; Alvarez-Fernández et al., 2003; Razeto and Valdés, 2006). Peach trees are Strategy I plants, and Fe uptake by these plants is preceded by a reduction step from $\mathrm{Fe}^{+3}$ to $\mathrm{Fe}^{+2}$ (Tagliavini and Rombola, 2001). The soluble Fe extracted with water from dried soil samples has been shown to be ineffective as a diagnostic tool to determine the amount of $\mathrm{Fe}$ available to leaves (Sadzawka et al., 2008; Razeto and Valdés, 2006). It has been suggested that the analysis of active iron $\left(\mathrm{Fe}^{+2}\right)$ extracted with acid from fresh samples would be a better indicator of the iron that is available to plants (Zohlen, 2000). Using this analysis, Sadzawka et al. (2008) found that there was a greater correlation between the degree of leaf symptoms and the level of active iron $\left(\mathrm{Fe}^{+2}\right)$ found in the sample.

Determinations of active iron have also been found to be useful in studies of iron deficiency in avocado leaves (Neaman and Aguirre, 2007; Ruiz et al., 2008) and in peach leaves (Koseoglu and Acikgoz, 1995). Other tissues of fruit trees, such as flowers, have been used as diagnostic tools for iron (Abadia et al., 2000).

Iron deficiency decreases vigor, yield and fruit quality in many species, and it affects bud development in the subsequent season (Tagliavini and Rombolá, 2001). Additionally, iron deficiency decreases carbohydrate reserves in the roots (Ruiz et al., 2008). The development of iron chlorosis symptoms in peach orchards is known to affect tree growth and to reduce fruit yield and quality (Alvarez-Fernándes et al., 2003). Of all the tree species, peaches tend to be more susceptible to developing iron deficiency chlorosis, which can be expensive and difficult to correct (Mengel and Kirkby, 2001; Tagliavini and Rombolá, 2001). The use of Fe deficiency-tolerant genotypes as rootstocks is a reliable solution to prevent iron chlorosis (Socías et al., 1995). Indeed, one of the successful strategies for solving problems with calcareous soils and iron chlorosis is the use of tolerant or resistant rootstocks, which appear to improve iron assimilation by the plant. Giorgi et al. (2005) found that the type of peach rootstock grown in calcareous soils can affect vegetative qualities, productivity, fruit quality and nutritional attributes. The well-known Nemaguard rootstock, which is used worldwide, has been reported to be an iron chlorosis-sensitive rootstock (Ruiz et al., 1984; Tagliavini and Rombolá, 2001).

There have been reports of new rootstocks that resist the development of chlorosis in calcareous soils. According to Romera et al. (1991), the rootstock Nemaguard is more susceptible to iron chlorosis induced by calcium bicarbonate than the hybrid GF 677. Additionally, Tsipouridis et al. (2005) found that the GF 677 rootstock was very efficient in dry, calcareous soils, and its grafted scion cultivars achieved higher concentrations of foliar iron. Loreti and Massai (2006) also reported that the rootstocks MRS 2/5 and Cadaman were fairly tolerant of iron deficiency chlorosis in calcareous soils. According to Iglesias et al. (2004), the Nemaguard and Nemared rootstocks 
showed the greatest sensitivity to iron chlorosis in calcareous soils, and while GxN 15 and MRS 2/5 were less affected, GF 677 was the only rootstock that did not develop chlorosis.

The objective of this study was to evaluate the effect of calcareous soils on vegetative growth, productivity and intensity of leaf chlorosis symptoms in six peach rootstocks, including the traditional Nemaguard rootstock and the new rootstocks Atlas, MRS 2/5, Cadaman, GF 677 and GxN 15, grafted with 'Ruby Diamond' nectarines. The study was conducted over a period of four years.

\section{Materials and methods}

'Ruby Diamond' nectarine scions were grafted (by the Univiveros and Requinoa Nurseries) onto Nemaguard, Atlas, MRS 2/5, Cadaman, GF 677 and GxN 15 peach rootstocks and were grown for four years in $100 \mathrm{~L}$ containers at the Estación Experimental de Pirque UC located in Pirque

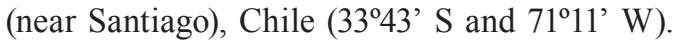
This location has a warm temperate climate. The $100 \mathrm{~L}$ containers were filled with a sandy loam calcareous soil (previously sterilized with methyl bromide) containing $6.3 \%$ active $\mathrm{CaCO}_{3}(\mathrm{pH} 8.0)$ with an intermediate level of available iron $(5 \mathrm{mg}$ $\mathrm{kg}^{-1}$ DTPA-extracted). All containers were dripirrigated to achieve tensiometer readings of 20 $\mathrm{cb}$, and the soil fertility level (originally $\mathrm{N}: 18 \mathrm{mg}$ $\mathrm{kg}^{-1}$, P: 9 mg kg-1, K: $324 \mathrm{mg} \mathrm{kg}^{-1}, \mathrm{Zn}: 1 \mathrm{mg} \mathrm{kg}{ }^{-1}$ and $\mathrm{Mn}: 5 \mathrm{mg} \mathrm{kg}^{-1}$ ) was maintained with annual applications of $100 \mathrm{~g}$ potassium nitrate (through the irrigation water). The experiment followed a completely randomized design with 12 replications. The experimental unit was each grafted rootstock in an individual container (spaced $5 \mathrm{~m}$ apart), and the treatments were the rootstocks Nemaguard, Atlas, MRS 2/5, Cadaman, GF 677 and GxN 15, all of which were grafted with Ruby Diamond nectarine.

Pruning was performed by removing half of all the shoots produced in a year during winter rest. Measurements of the fruit (yield and fruit number), trunk diameter and weight of pruning material were performed at the end of the experiment $\left(4^{\text {th }}\right.$ season). The iron concentration was evaluated in 30 randomly collected leaves per plant in January using a chemical analysis method based on the active iron fraction $\left(\mathrm{Fe}^{+2}\right)$ (Katyal and Sharma, $1980,1984)$. The procedure was carried out using 30 fresh leaves per plant at 24 hours after collection under acidic conditions with orthophenanthroline. All these determinations were complemented by leaf chlorophyll measurements using a Minolta SPAD-502 chlorophyll meter; 30 leaves per plant were measured at random. According to these measurements, a leaf chlorosis scale was established, with 1.0 for no chlorosis (more than 40 Spad units), 2.0 for mild chlorosis (30 to 40 Spad units), and 3.0 for severe chlorosis (less than 30 Spad units). The soil in the containers was regularly analyzed to determine the $\mathrm{pH}$, electrical conductivity and basic fertility.

All collected data were analyzed with ANOVA, and the means were separated by the TukeyKramer test at $\mathrm{P}=0.05$.

\section{Results and discussion}

The trunk diameter of the different rootstocks increased significantly during this study, with GF 677, GxN 15, Cadaman and Atlas showing larger values when compared with Nemaguard and MRS 2/5. Cadaman and Atlas had the highest pruning weight (a measure of vegetative growth), while GF 677, GxN 15 and MRS 2/5 had intermediate weights. Nemaguard showed the lowest weight and vigor (Table 1).

When measured at the end of the experiment, the trunk diameters of GF 677, GxN 15, Cadaman and Atlas were significantly larger than those of Nemaguard and MRS 2/5. Cadaman and Atlas had significantly higher pruning weights, GF 677 and GxN 15 had intermediate weights, and MRS 2/5 together with Nemaguard had the lowest weights (Table 1). 
Table 1. Vegetative growth of Ruby Diamond nectarine trees grafted onto different peach rootstocks during the $4^{\text {th }}$ growing season.

\begin{tabular}{lcc}
\hline Rootstock & $\begin{array}{c}\text { Trunk diameter } \\
(\mathrm{mm})\end{array}$ & $\begin{array}{c}\text { Pruning weight } \\
\left(\mathrm{g} \mathrm{tree}^{-1}\right)\end{array}$ \\
\hline Cadaman & $43.8 \mathrm{ab}$ & $705 \mathrm{a}$ \\
Atlas & $40.2 \mathrm{ab}$ & $691 \mathrm{a}$ \\
GxN 15 & $46.6 \mathrm{ab}$ & $450 \mathrm{~b}$ \\
GF 677 & $52.8 \mathrm{a}$ & $442 \mathrm{~b}$ \\
MRS 2/5 & $20.8 \mathrm{c}$ & $254 \mathrm{c}$ \\
Nemaguard & $30.2 \mathrm{bc}$ & $250.0 \mathrm{c}$ \\
\hline
\end{tabular}

Different letters in a column indicate significant differences according to the Tukey-Kramer test at $\mathrm{P}=0.05$.

The Cadaman and Atlas peach rootstocks produced the greatest overall vegetative growth in the calcareous soil utilized in this study. In contrast, Nemaguard and MRS 2/5 showed the least vegetative growth, which could also be due to the mild dwarf phenotype of MRS 2/5 (Loreti and Massai, 2006). Because Nemaguard is not a dwarfing rootstock, the low growth could be due to a greater sensitivity to iron deficiency.

By the fourth growing season, the yield per tree was highest in Atlas and Cadaman, while GF 677, GxN 15 and MRS 2/5 showed intermediate yields. Nemaguard exhibited the lowest yield (Table 2). The individual fruit weight of MRS 2/5 was significantly higher than that of all other rootstocks except GxN 15, while Cadaman followed by Atlas had the lowest fruit weights (Table 2).

Table 2. Yield and fruit weight in Ruby Diamond nectarine trees grafted onto different peach rootstocks during the $4^{\text {th }}$ growing season.

\begin{tabular}{lcc}
\hline Rootstock & $\begin{array}{c}\text { Individual fruit } \\
\text { weight }(\mathrm{g})\end{array}$ & $\begin{array}{c}\text { Yield per tree }(\mathrm{kg} \\
\text { tree }\end{array}$ \\
\hline Atlas & $128 \mathrm{~b}$ & $7.4 \mathrm{a}$ \\
Cadaman & $110 \mathrm{c}$ & $7.2 \mathrm{a}$ \\
GxN 15 & $148 \mathrm{ab}$ & $4.8 \mathrm{~b}$ \\
GF 677 & $120 \mathrm{~b}$ & $4.4 \mathrm{~b}$ \\
MRS 2/5 & $192 \mathrm{a}$ & $4.2 \mathrm{~b}$ \\
Nemaguard & $132 \mathrm{~b}$ & $3.6 \mathrm{c}$ \\
\hline
\end{tabular}

Different letters in a column indicate significant differences according to the Tukey-Kramer test at $\mathrm{P}=0.05$.
The highest total iron concentrations in leaves were observed in GF 677, GxN 15 and Cadaman when compared with the other rootstocks (Table 3). These leaf iron values are high according to the standards indicated by Reuther and Robinson (1997). These results confirm the insensitivity of the total Fe content for the diagnosis of leaf deficiency, as has been reported by many other authors. Conversely, as shown in Table 3, leaf ferrous iron $\left(\mathrm{Fe}^{+2}\right)$ content in most rootstocks was higher than that in Nemaguard. In Atlas, this difference was not statistically significant. The inaccuracy of using total Fe content to evaluate the iron status in peaches must again be emphasized here. According to the visual evaluation scale used for determining the degree of iron chlorosis, the symptoms were severe in Nemaguard; mild in Atlas; mild to non-existent in GxN 15, Cadaman and MRS 2/5; and nonexistent in GF 677. These observations agree with those of Cinelli et al. (2004) in the sense that the GF 677 rootstock has a high tolerance to iron chlorosis. Similar results have been reported by Iglesias et al. (2004). With regard SPAD measurements, Nemaguard exhibited the lowest value (21.6 units) when compared with the other rootstocks, whereas GF 677 showed the highest value (42.6 units). These data may indicate that, for reasons not yet well understood, these rootstocks are able to extract $\mathrm{Fe}^{+2}$ from soil more efficiently and enhance chlorophyll synthesis in leaves when compared with Nemaguard. Normally, under aerobic conditions, plants actively absorb $\mathrm{Fe}^{+2}$ after the reduction of soil $\mathrm{Fe}^{+3}$ by a reductase in the root plasma membrane (Romheld, 1987). It is possible that the enhanced iron nutrition obtained when using GF-677, GxN 15 and Cadaman rootstocks is due to the plants' ability to efficiently absorb Fe. According to Mengel and Kirby (2001), these plants are capable of excreting organic substances with iron-chelating abilities, such as citric acid, caffeic acid and others, into the rooting medium, thus improving iron absorption by the roots and preventing further oxidation or inactivation. 
Table 3. Leaf iron content (total $\mathrm{Fe}$ and $\mathrm{Fe}^{+2}$ ), SPAD values and degree of leaf chlorosis during the $4^{\text {th }}$ growing season.

\begin{tabular}{lcccl}
\hline Rootstocks & $\begin{array}{c}\text { Total Fe } \\
\left(\mathrm{mg} \mathrm{kg}^{-1}\right)\end{array}$ & $\begin{array}{c}\mathrm{Fe}^{+2} \\
\left(\mathrm{mg} \mathrm{kg}^{-1}\right)\end{array}$ & $\begin{array}{c}\text { Leaf SPAD } \\
\text { values }\end{array}$ & Degree of chlorosis \\
\hline GF 677 & $357 \mathrm{a}$ & $26.4 \mathrm{a}$ & $42.6 \mathrm{a}$ & 1.0 (none) \\
GxN 15 & $356 \mathrm{a}$ & $25.1 \mathrm{a}$ & $42.1 \mathrm{a}$ & 1.5 (mild to none) \\
Cadaman & $359 \mathrm{a}$ & $23.0 \mathrm{a}$ & $41.9 \mathrm{ab}$ & 1.5 (mild to none) \\
MRS 2/5 & $319 \mathrm{~b}$ & $23.5 \mathrm{a}$ & 42.0 & 1.5 (mild to none) \\
Atlas & $326 \mathrm{~b}$ & $19.2 \mathrm{ab}$ & $36.8 \mathrm{~b}$ & 2.0 (mild) \\
Nemaguard & $330 \mathrm{ab}$ & $12.3 \mathrm{~b}$ & $21.6 \mathrm{c}$ & 3.0 (severe) \\
\hline
\end{tabular}

Different letters in a column indicate significant differences according to the Tukey-Kramer test at $\mathrm{P}=0.05$.

It can be concluded that under the experimental conditions described above, the rootstocks GF 677 , GxN 15, Atlas, MRS 2/5 and Cadaman were more better able to resist iron deficiency and iron chlorosis compared with Nemaguard. Cadaman and Atlas showed higher vegetative growth, higher yields, and an increased trunk diameter when compared with Nemaguard and MRS2/5. These experiments confirm the inefficiency of total iron analysis in leaves as a tool for diagnosing iron deficiency. Leaf ferrous iron $\left(\mathrm{Fe}^{+2}\right)$ was found to be a very sensitive tool for the determination of iron status, with higher $\mathrm{Fe}^{+2}$ levels in GF 677, GxN, Cadaman and MRS $2 / 5$ and lower $\mathrm{Fe}^{+2}$ levels in Nemaguard. These results are closely linked to leaf foliar symptoms and SPAD values and are generally in agreement with the reports by Romera et al. (1991) and Tsipouridis et al. (2005) in peach trees.

\section{Resumen}

C. Sotomayor, R. Ruiz y J. Castro. 2014. Crecimiento vegetativo, productividad y tolerancia a la deficiencia de hierro en seis portainjertos de duraznero creciendo en suelo calcáreo. Cien Inv. Agr. 41(3):403-409. La deficiencia de hierro es un problema mayor que afecta a muchos cultivos frutales en suelos calcáreos. Se realizó un estudio durante cuatro años para evaluar el efecto de suelos calcáreos en el comportamiento vegetativo y productivo de seis portainjertos de duraznero (Nemaguard, Atlas, MRS 2/5, Cadaman, GF 677 y G×N 15) injertados con el nectarino Ruby Diamond. Los árboles fueron plantados en contenedores de 100 L conteniendo un suelo franco-arenoso y calcáreo (6,3\% de carbonato de calcio activo), con $\mathrm{pH} 8,0$ y un nivel medio de hierro aprovechable $\left(5 \mathrm{mg} \mathrm{kg}^{-1} \mathrm{de} \mathrm{Fe}^{+2}\right)$. El diámetro de tronco a la cuarta temporada y final de este estudio fue mayor en GF 677, G×N 15, Cadaman y Atlas mientras que Nemaguard y MRS 2/5 mostraron diámetros promedio menores. Con respecto al peso de la poda (una medida del crecimiento vegetativo) Cadaman y Atlas presentaron los pesos mayores, G×N 15 y GF 677 fueron intermedios, mientras que MRS 2/5 y Nemaguard lograron los menores. Al cuarto año la producción por planta fue mayor en Atlas y Cadaman, mientras que en Nemaguard fue la más baja. En cuanto a peso individual de fruto, MRS 2/5 y G $\times$ N 15 alcanzaron la cifra mayor, particularmente comparado con Cadaman. Respecto a la deficiencia de hierro (clorosis férrica), los síntomas más severos los mostró Nemaguard (12 mg $\mathrm{kg}^{-1} \mathrm{de} \mathrm{Fe}^{+2}$ ). No se desarrolló clorosis en GF 677, hubo ligera clorosis en Atlas y leve a ninguna en los otros portainjertos. Todos los portainjertos, especialmente GF 677, mostraron una mejor respuesta que Nemaguard en las mediciones de clorofila a través de la técnica SPAD.

Palabras clave: Clorosis férrica, $\mathrm{Fe}^{+2}$, portainjerto de duraznero, SPAD, suelo calcáreo. 


\section{References}

Abadía, J., M. Tagliavini, R. Grasa, R. Belkhodja, A. Abadía, and M. Sanz. 2000. Using the flower Fe concentration in estimating chlorosis status in fruit tree orchards: a summary report. J.Plant Nutr. 23: 2023-2033.

Alvarez-Fernández, A., P. Paniagua, J. Abadía, and A. Abadía 2003. Effects of Fe defficiency chlorosis on yield and fruit quality in peach. J.Agric. Food Chem. 51:5738-5744

Cinelli,F., I. Tamantini, and C. Iacona. 2004. Nutritional (Fe-Mn) interactions in 'Big Top' peach plants as influenced by the rootstock and by the soil $\mathrm{CaCO}_{3}$ concentration. Soil Sci. Plant Nutr. 50:1097-1102.

Giorgi, M., F. Capocasa, J. Scalzo, G. Murri, M. Battino, and B. Mezzetti. 2005. The rootstock effects on plant adaptability, production, fruit quality and nutrition in peach. Scientia Horticulturae 107:36-42.

Gruber, B., and H. Kosegarten 2002. Depressed growth of non-chlorotic vine grown in calcareous soil is an iron deficiency symptom prior to leaf chlorosis. J. Plant Nutr. Soil Sci. 165:111117.

Iglesias, I., R. Montserrat, J. Carbó, J. Bonany, and M. Casals. 2004. Evaluation of agronomical performances of several peach rootstocks in Lleida and Girona (Catalonia). Acta Horticulturae 658: 658:341-348.

Katyal, J., and B. Sharma. 1980. A new technique of plant analysis to resolve iron chlorosis .Plant and Soil 55:105-119.

Katyal, J., and B. Sharma.1984. Some modifications in the assay of $\mathrm{Fe}+2$ in 1-10, o-phenantrolina extracts of fresh plant tissues. Plant and Soil 79:449-450.

Koseoglua, T. 1995. Investigation of relationships between iron status of peach leaves and soil properties. Journal of Plant Nutrition 18:18451859.

Koseoglua, T., and V. Açikgöz. 1995. Determination of iron chlorosis with extractable iron analysis in peach leaves. Journal of Plant Nutrition 18:153161.
Loreti, F., and R. Massai. 2006. State of the art on peach rootstocks and orchard systems. Acta Horticulturae 713:253-268.

Mengel, K. 1995. Iron availability in plant tissues - iron chlorosis on calcareous soil. Nutrition in Soils and Plants: 389- 397.

Mengel, K., and E. Kirby. 2001. Principles of plant nutrition. Dordrecht: Kluwer Academic Publishers. 849 pp.

Neaman, A., and L. Aguirre. 2007. Comparison of different methods for diagnosis of iron deficiency in avocado. Journal of Plant Nutrition, 30 (6):1097-1108.

Razeto, B., and g. Valdés. 2006. Análisis de hierro soluble en tejidos para diagnosticar el déficit de hierro en nectarino. Agricultura Técnica (Chile) 66:216-220.

Reuter, D., and J. Robinson. 1997. Plant Analysis. An Interpretation Manual CSIRO Publishing, Collingwood, Vic. 572 pp.

Romera, F., E. Alcantara, and M. De la Guardia. 1991. Characterization of the tolerance to iron clorosis in different peach rootstocks grown in nutrient solution. I: Effect of bicarbonate and phosphate. Plant and Soil 130 (1-2): 115 -119.

Romheld, V. 1987. Different strategies for iron acquisition in higher plants. Physiologia Plantarum 70:231-234.

Romheld, V. 2000. The chlorosis paradox: Fe inactivation as a secondary event in chlorotic leaves of grapevine. Journal of Plant Nutrition 23:16291643.

Ruiz, R., C. Sotomayor, and G. Lemus. 1984. Corrección de clorosis férrica en nectarinos y efecto residual. Agricultura Técnica (Chile) 44:305309.

Ruiz, R., R. Ferreyra, and C. Barrera. 2008. Deficiencias de hierro en paltos. Avances en el diagnóstico. Implicancias productivas y en los niveles de reserva. Proceedings of the 6th World Avocado Congress. Viña del Mar, Chile. p.132.

Sadzawka, A., R. Ruiz, and J. Villanueva. 2008. Estimación del Fe (II) foliar para el diagnóstico de la clorosis férrica en plantas. Actas $51^{\circ}$ Congreso Agronómico de Chile. Simiente (Chile) 70:8687. 
Socías, I., R. Company, J. Gómez-Aparisi, and A. Felipe. 1995. Iron nutrition in soils and plants, $a$ genetical approach to iron chlorosis in deciduous fruit trees. In: Abadía, J. (ed.). Kluwer Academic Publishers. Dordrecht, The Netherlands. p. 167-174.

Tagliavini, M., and A. Rombolá. 2001. Iron deficiency and chlorosis in orchard and vineyards ecosystems. European Journal of Agronomy 15:71-92.

Toselli, M., B. Marangoni, and M. Tagliavini. 2000. Iron content in vegetative and reproductive or- gans of nectarine trees in calcareous soils during the development of chlorosis. European Journal of Agronomy 13: 279 - 286.

Tsipouridis, C., T. Thomidis, and K. Anestis. 2005. Effect of peach cultivars, rootstocks and Phytophthora on iron chlorosis. World Journal of Agricultural Sciences 1:137-142.

Zohlen, A. 2000. Use of 1,10-phenanthroline in estimating metabolically active iron in plants. Communications in Soil Science and Plant Analysis 31:481-500. 
